\title{
Language-related computer use: Focus on young L2 English learners in Sweden*
}

\author{
PIA SUNDQVIST \\ Karlstad University, Sweden \\ (email: pia.sundqvist@kau.se) \\ LISS KERSTIN SYLVÉN \\ University of Gothenburg, Sweden \\ (email: lisskerstin.sylven@ped.gu.se)
}

\begin{abstract}
This paper presents findings from a study investigating young English language learners (YELLs) in Sweden in $4^{\text {th }}$ grade $(\mathrm{N}=76$, aged 10-11). Data were collected with the help of a questionnaire and a one-week language diary. The main purpose was to examine the learners' L2 English language-related activities outside of school in general, and their use of computers and engagement in playing digital games in particular. A comparison is made between language-related activities in English, Swedish, and other languages. Another purpose was to see whether there is a relationship between playing digital games and (a) gender, (b) L1, (c) motivation for learning English, (d) self-assessed English ability, and (e) self-reported strategies for speaking English. In order to do so, the sample was divided into three digital game groups, (1) non-gamers, (2) moderate, and (3) frequent gamers ( $\geq 4$ hours/week), based on diary data (using self-reported times for playing digital games in English). Results showed that YELLs are extensively involved in extramural English (EE) activities $(M=7.2 \mathrm{hrs} / \mathrm{w})$. There are statistically significant gender differences, boys $(11.5 \mathrm{hrs} / \mathrm{w})$ and girls $(5.1 \mathrm{hrs} / \mathrm{w}$; $p<.01)$, the reason being boys' greater time investment in digital gaming and watching films. The girls, on the other hand, spent significantly more time on pastime language-related activities in Swedish $(11.5 \mathrm{hrs} / \mathrm{w})$ than the boys $(8.0 \mathrm{hrs} / \mathrm{w} ; p<.05)$, the reason being girls' greater time investment in facebooking. Investigation of the digital game groups revealed that group (1) was predominantly female, (2) a mix, and (3) predominantly male. YELLs with an L1 other than Swedish were overrepresented in group (3). Motivation and self-assessed English ability were high across all groups. Finally, regarding the self-reported strategies, code-switching to one's L1 was more commonly reported by non- and moderate gamers than frequent gamers.
\end{abstract}

Keywords: Computer-assisted language learning, computer games, English language learning, self-report, ESL students, schoolchildren

* We would like to thank the Erik Wellander Foundation and the Center for Language and Literature in Education (CSL), Karlstad University, for funding our pilot study. 


\section{Introduction and aims}

In contemporary Sweden, the prevalence of English is great, not least thanks to various media. To give one example, Sweden broadcasts English-speaking films and TV productions in the original language with Swedish subtitles. As a contrast, in countries such as France, Germany, and Spain, Anglophone productions are instead dubbed. Films and TV shows are thus two sources of authentic English in Swedish society, others are music, digital games, and - naturally - a great many Internet sites in English just a click away: in the year 2011, 85\% of the population had access to the Internet from their homes (Findahl, 2011). Furthermore, many commercials and advertisements use English expressions to boost their message. Thus, many Swedes come in contact with authentic English more or less on a daily basis. This situation is not unique to Sweden and there is a growing number of studies within the field of second language acquisition and computer-assisted language learning (CALL) that focus on the relationship between out-of-school informal contacts with English and proficiency (see, e.g., Forsman, 2004; Kuppens, 2010; Lindgren \& Muñoz, 2012; Olsson, 2011; Persson, 2011; Piirainen-Marsh \& Tainio, 2009; Sundqvist, 2009, 2011; Sylvén, 2010; Sylvén \& Sundqvist, 2012). Since children today are exposed to English from a very young age, empirical studies targeting learners in primary school are highly relevant. The purpose of this article is to present a study among young English language learners (YELLs), aged 10-11, in Sweden. Based on data collected with the help of a questionnaire and a language diary, we account for the learners' pastime language-related computer use in English and compare it with their languagerelated computer use in Swedish and other languages. The sample is then divided into three groups depending on the amount of time spent on playing digital games in English: non-gamers, moderate gamers, and frequent gamers. These digital game groups are examined with regard to gender, first language (L1), motivation for learning English, self-assessed English ability, and self-reported learner strategies related to speaking English.

In what follows, we begin by describing in more detail the situation for English in Sweden and also discuss extramural English (EE), a term introduced by Sundqvist (2009) in reference to all types of English-related activities that learners come in contact with or are engaged in outside the walls of the English classroom, generally on a voluntary basis (see also Sundqvist, 2011). Then we provide a theoretical overview of previous CALL studies, with a particular focus on studies geared toward YELLs. After that we describe our study and discuss its findings, before the article closes with some concluding remarks and suggestions for further research.

\section{English in Sweden}

Replacing German, English became the first foreign language (FL) in Swedish compulsory school in 1962 and, as of the 2011 curriculum for the compulsory school, English is an obligatory subject already introduced in the first grade (The Swedish National Agency of Education, 2011a). In addition, according to the most recent curriculum for upper secondary school, also implemented in the year 2011, a pass grade in English is a requirement for acceptance to upper secondary school 
(The Swedish National Agency of Education, 2011b). To add to the special status of English, it remains the only mandatory language arts subject throughout the school system. Some schools also offer content and language integrated learning, using English as the medium of instruction in non-language subjects, for instance in upper secondary school (see, e.g., Sylvén, 2010) but even more so within higher education (Airey, 2009; Söderlundh, 2010). Finally, outside school and academia, English is used as an official language in a number of Swedish corporations in the private sector. ${ }^{1}$

It is fair to say, then, that English has a particular status in Swedish society and in recent years there has even been a debate as to whether English should be regarded as a second language (L2) rather than as a FL (see, e.g., Hyltenstam, 2002; Viberg, 2000). This ESL-EFL controversy is in line with Ushioda's (2013) similar discussion developed from Kachru's (1985) three concentric circles of English: inner circle (native Anglophone countries), outer circle (postcolonial territories), and expanding circle (countries where English is taught as a FL). Ushioda emphasizes that the expanding circle has become expanded and diversified to such an extent that in some countries (including Sweden), the presence of English is simply pervasive and a great number of people in the expanding circle are more fluent speakers of English than people in outer-circle countries, where English is an official L2. As for the suggestion that many Swedes are highly proficient English speakers, it needs to be stressed that in particular young Swedes often are expected by the general public to have a good knowledge of English (Sundqvist, 2009). Bearing all these circumstances in mind, it is not surprising that empirical studies among secondary and upper secondary learners in Sweden (as well as in Finland, in many ways a similar country) show that EE correlates positively with proficiency (Forsman, 2004; Olsson, 2011; Sundqvist, 2009, 2011; Sylvén, 2010). However, studies on primary school learners remain scarce, although there are some (see, e.g., Lindgren \& Muñoz, 2012; Sylvén \& Sundqvist, 2012). It is noteworthy that in the latest Swedish nationwide survey of the school subject English, more than half of the $5^{\text {th }}$ graders indicate that they have learned English as much, or more, outside of school as in school (The Swedish National Agency of Education, 2004). There are also international studies that point in the same direction (see, e.g., Kuppens, 2010; Persson, 2011), thereby stressing the relevance of researching EE among young learners in more depth, not only nationally, but also internationally.

\section{Background: Previous research on CALL and L2 English learners}

While the number of studies into the learning of English as an L2 or a FL among young learners is low, there has been a welcome growth over the last few years (see, e.g., Enever, 2011; Lindgren \& Muñoz, 2012; Nikolov, 2009). ${ }^{2}$ Further, volumes as well as particular studies on the relationship between computer use and language learning have rapidly increased in the last decade (see, e.g., deHaan, Reed \& Kuwada, 2010; Forsman, 2004; Greenberg, Sherry, Lachlan, Lucas \& Holmstrom, 2010; Olsson, 2011; Piirainen-Marsh \& Tainio, 2009; Ranalli, 2008; Reinders, 2012;

1 The Volvo Group is one example (http://vakanser.se/jobb/underhallschef +82/).

2 The term $L 2$ is henceforth used for both second and foreign languages. 
Sundqvist, 2009). However, research focusing on the combination of CALL and YELLs is still scarce. In this overview, we start by briefly mentioning some of the studies relating to computers and language learning in general, before focusing on those dealing specifically with CALL and YELLs.

Gee (2007) formulates 36 principles in connection with digital gameplay and literacy and argues, among other things, that digital games offer close to ideal circumstances for language learning to take place. To summarize only some of Gee's principles: digital games are perceived as motivating, they encompass target language input as well as output, co-players need to negotiate for meaning and they can do so in a secure and affirming atmosphere. Support for this seemingly close relationship between gaming and language learning has increased thanks to the results from a number of empirical studies during the last decade. In an American study of two groups of Chinese advanced learners of English, where one group received regular ESL training and the other played a multi-modal online game for a number of hours, findings indicate that playing digital games accommodates "the specific L2 learning objectives of vocabulary acquisition, reading comprehension skills, and conversational fluency" (Rankin, McNeal, Shute \& Gooch, 2008: 48). Positive results were also found in a Japanese small-scale study of English university students playing a massively multiplayer online role-playing game (MMORPG), Wonderland. The researcher, Peterson (2012), concludes that all learners made progress with regard to, for example, the appropriate use of various aspects of politeness: greetings, informal language, humor, leave-takings, and small talk. As for the relation between speaking English and digital gaming, research carried out among Swedish adolescents shows that involvement in EE activities (i.e., including gaming) correlates with self-reported anxiety related to speaking English (Sundqvist, 2009). Phrased differently, youths who spent a great deal of time on EE activities reported feeling less anxious about speaking English than those who spent less time on such activities. Interestingly, reduced anxiety levels were particularly salient among digital gamers (op. cit.: 200). Results in the same vein are reported in a study on two boys engaged in playing Final Fantasy $X$ in their homes: Piirainen-Marsh and Tainio (2009) observed the playful linguistic spoken interactivity between the players, thus emphasizing the sociocognitive side of gameplay. Finally, as an undergraduate student, Purushotma (2005) played the single-player simulation game The Sims in its German version, and in so doing taught himself German. Thus, it seems that regardless of whether one plays single, multiplayer, or massively multiplayer games, multifaceted opportunities for language learning are often inherent features of digital games (cf. Gee, 2007).

In a recent edited volume, Reinders (2012) brings together a number of scholars with contributions in the field of digital gaming and L2 learning and teaching, among them Chik (2012), who shows the inherent potential for autonomous language learning through digital gaming. She found that players to a larger extent than non-players volunteered information to others, and that they interactively resolved language-related problems. Reichl (2012) points to the connection between gaming and morphosyntactic proficiency in the L2. Further, in a study among Thai university students playing a MMORPG (Ragnarok Online), Reinders and Wattana (2011) saw a clear increase in the students' willingness to communicate in English, even though, at the same time, their self-assessed confidence in using English 
remained unaffected. According to the authors, the findings can be explained by cultural and affective factors, which thus need to be taken into account if gaming is to be implemented in L2 English classrooms. Other studies suggest that digital gaming may be particularly beneficial for vocabulary acquisition (see, e.g., Cheung \& Harrison, 1992; Miller \& Hegelheimer, 2006; Ranalli, 2008; Rankin, Gold \& Gooch, 2006). A close relative to vocabulary is collocations and a good command of collocational patterns is indicative of L2 fluency (Boers, Eyckmans, Kappel, Stengers \& Demecheleer, 2006). In another contribution to Reinders (2012), Wu, Franken and Witten (2012) describe specifically designed collocation games to be used by L2 English learners. They highlight the flexibility of using a computer (as opposed to paper-based material) and also the endless number of collocations that can be generated by the computer, which in turn helps the learning process. The conclusion drawn is that games construed for the purpose of learning collocations "motivate learners to want to continue playing them and also push their performance beyond simple language manipulation" (op. cit.: 227). In our own chapter (Sundqvist \& Sylvén, 2012), we identify a clear pattern from three separate studies with regard to the correlation between EE, above all in the form of digital gaming, and L2 English proficiency among learners of various ages.

A clearly positive relation between computer use and learning in general has been shown in a well-known "hole in the wall" project in India (Mitra, Dangwal, Chatterjee, Jha, Bisht \& Kapur, 2005). Computers were made publicly available for children who could use them at their own leisure. The findings suggest an immense inherent power of information technology when tied up with group self-instruction (cf. massively multiplayer games) and add to the general belief that "children benefit from exposure to computers as they use it for multiple purposes" (Mitra et al., 2005: 407).

Among the YELL studies that exist, Ramírez Verdugo and Alonso Belmonte (2007) merits attention. They studied the effects of CALL on listening comprehension skills among Spanish YELLs (aged 6). They found that the experimental group (where pupils worked with digital story-telling during one of two lessons per week) outperformed the control group (where pupils were restricted to textbooks) both on vocabulary and listening comprehension tests. The authors attribute the superior performance by the experimental group to the fact that digital stories can be replayed any number of times by the individual pupil. In the same vein, Odera (2011) found that the use of radio technology in primary education in Kenya is helpful for L2 English learning, particularly regarding pronunciation. Set in a completely different context, Turgut and Irgin (2009) studied Turkish children playing digital games in English at Internet cafés. Their results suggest that the involvement in digital gaming indeed stimulates learning, in particular vocabulary. In yet another context, Cobb and Horst (2011) examined Canadian 12- and 13-year-olds using Word Coach, a specifically designed digital game training program for vocabulary learning, and found that in order for learning to become consolidated, longer periods of play are required. A final study is Kuppens (2010). Her study is set among 11-year-olds in the Flemish Dutch-speaking area in Belgium and investigates the influence of various media (e.g., computer games and English-produced TV programs/movies with Dutch subtitles) on learners' oral translation skills. She found a positive correlation 
between such skills and digital gaming. In sum, there are promising findings in the area of CALL and YELLs, which leads on to our own study.

\section{The study}

Our study is based on data originally collected in 2010 for a large pilot study among learners in primary school, grades $4-6$. Results based on the data for the $5^{\text {th }}$ graders have been reported in Sylvén and Sundqvist (2012). The focus of the present study is on the youngest participants, i.e., the learners in grade 4 (aged 10-11). In this section, we present the research questions and describe the sample, materials, and methods that we used.

\subsection{Research questions}

Five research questions guided the present study:

1 What types of extramural language-related activities, in English and Swedish, are the learners engaged in?

2 How much time do the learners spend on various language-related activities (English and Swedish)?

3 What language-related use of computers do the learners report (English and Swedish)?

4 In particular, what are the learners' digital gaming habits?

a. How much do they play (English and Swedish)?

b. What types of games do they play (English and Swedish)?

5 Is there a relationship between playing digital games in English and

a. gender?

b. L1?

c. motivation for learning English?

d. self-assessed English ability?

e. self-reported strategies related to speaking English?

\subsection{Sample, materials, and methods}

The sample is drawn from five classes at four schools in the same municipality, a medium-sized Swedish town. The schools are situated in different areas: two in the city, one on the outskirts of town, and one in the countryside. Prior to the start of the study, written forms of consent were collected from the guardians. In total, 112 learners (47 boys, 65 girls) were approached and $76(68 \%)$ returned affirmative forms ( 25 boys, 51 girls). In comparison, then, the ratio of participation is higher among the girls $(78 \%)$ than the boys $(53 \%)$. Although speculative, we believe that the fact that no reminders were sent out explains most of the external attrition. In addition, it is fairly common for children to lose a sheet of paper they are supposed to take home and later return to their teacher - and perhaps more common for boys to do so than for girls? To conclude, the overall ratio of participation is considered satisfactory, but caution is called for when interpreting the results. We will return to this in our discussion. 
We collected two sets of materials, a questionnaire and a language diary. The questionnaire mapped the learners' EE activities as well as providing information about other variables (e.g., experiences of traveling abroad, L1, motivation, and selfassessed English ability) and was filled out at school during a lesson when one of the researchers was present. On the same occasion, a language diary was introduced by the researcher (for a sample page, see Appendix 1). The language diary was to be filled in daily at home for one week, with the purpose of yielding information about both the type and amount of EE activities. In all, seven different activities are given in the diary: reading books, reading newspapers/magazines, watching $T V$, watching films, using the Internet, playing digital games, and listening to music. There is also a final 'other' option. The same type of information was filled in also for languagerelated activities in Swedish as well as in any other language(s) that the learners might have come in contact with. The teachers used this diary as English homework that particular week. For the learners who forgot to fill in the diary, the teachers arranged time daily to do so in school. It ought to be mentioned that the language diary has been used in previous studies among upper secondary (Sylvén, 2007) and secondary (Olsson, 2011; Sundqvist, 2009) learners, but was slightly adapted to suit the present age group. Other methods for mapping language-related extramural activities have been used elsewhere; Forsman (2004) and Greenberg et al. (2010) provide alternative approaches. Finally, it is worth mentioning that formal assessments of English language proficiency among $4^{\text {th }}$ graders are neither part of the curriculum nor of routine English schoolwork in Sweden and, therefore, such data were unavailable.

It goes without saying that it is very difficult for young learners to remember to fill in all extramural "language-related" activities (as specified in the diary) they did in one day and exactly how much time they spent on each of the activities; they simply provide estimates. Thus, the diary relies on self-report and, therefore, has its flaws regarding reliability. However, all guardians were well informed via school parental meetings and also via the teachers' weekly e-message to the homes, where guardians were encouraged to remind their children regularly about the diary. Also, quantitative exploration of the questionnaire data largely corroborated the diary data, so we consider the data reliable even though, admittedly, some minor divergences were identified, for example, as regards the participants' habits of reading books in Swedish. Finally, in Sylvén and Sundqvist (2012), where an identical language diary was used for $5^{\text {th }}$ graders, reliability analyses regarding using the language diary as an instrument for measuring EE were indeed satisfactory.

As for the analytical part, all data were inputted manually into statistical software (SPSS 19) and double-checked by the researchers before statistical procedures and quantitative analyses commenced. In order to answer research question 5, i.e., whether there is a relationship between playing digital games and (a) gender, (b) L1, (c) motivation for learning English, (d) self-assessed English ability, and (e) selfreported strategies for speaking English, the sample was divided into three digital game groups based on diary data (namely, the total amount of time recorded for playing digital games in English): (1) non-gamers, (2) moderate gamers, and (3) frequent gamers. As previous research has shown that digital gaming may influence several aspects of L2 English proficiency, we decided to analyze the present 
data from the perspective of three digital game groups, thereby hoping to shed light upon the specific research questions proposed here.

\section{Results}

\subsection{Language-related extramural activities in English, Swedish, and other languages}

Based on language diary data, Table 1 shows the order of popularity of the languagerelated extramural activities in English and Swedish. Watching TV is the most popular activity for both languages, whereas least time is spent on reading newspapers and/or magazines and 'other'. As for EE, digital gaming is popular, and more time is spent on gaming in English as compared to doing so in Swedish. Independent samples $t$-tests for gender revealed statistically significant differences for the total time spent on EE (boys: 11.5 hours/week; girls: 5.1 hours/week; $p<.01$ ), for playing digital games (boys: 3.4 hours/ week; girls: .4 hours/week; $p<.01$ ), and for watching films (boys: 1.8 hours/week; girls: .6 hours/week; $p<.01)$. With regard to extramural Swedish, there were statistically significant gender differences for the total time (boys: 8.0 hours/week; girls: 11.5 hours/week; $p<.05$ ) and for using the Internet (boys: .5 hours/week; girls: 2.4 hours/week; $p<.05$ ).

As for extramural activities in other languages, the diary reports were so few that they come across as negligible, but perhaps the fact that the young learners brought forward five additional languages still deserves mentioning here: German (via a digital game, The Sims), Japanese (manga books), Norwegian (TV programs, films, books, and newspapers), Russian (music), and Spanish (the Internet and 'other' activities).

\subsection{Language-related computer use in English and Swedish}

The questionnaire and the language diary both provide data about the $4^{\text {th }}$ graders' language-related computer use. It seems clear that despite their young age, the

Table 1 Extramural English and Swedish activities in order of popularity and in total

\begin{tabular}{llllll}
\hline \hline & \multicolumn{2}{c}{ Extramural English } & & \multicolumn{2}{c}{ Extramural Swedish } \\
\cline { 2 - 3 } \cline { 5 - 6 } Order & Activity & Hours/week & & Activity & Hours/week \\
\hline \hline 1 & TV & 2.3 & & TV & 4.3 \\
2 & Digital games** & 1.4 & & Internet* & 1.8 \\
3 & Music & 1.4 & & Books & 1.1 \\
4 & Films** & 1.0 & & Films & 1.0 \\
5 & Internet & 1.0 & & Digital games & .8 \\
6 & Books & .1 & & Music & .7 \\
7 & Newspapers/magazines & .1 & & Newspapers/magazines & .4 \\
8 & Other & .1 & & Other & .2 \\
& Total** & 7.2 & & Total* & 10.3 \\
\hline \hline
\end{tabular}

*Significant gender-related difference at the .05 level.

**Significant gender-related difference at the .01 level. 
participants use computers for a wide array of activities. The Internet, for example, is used to access the few Swedish as well as English newspapers and magazines that are mentioned. The Internet is also used for accessing music, frequently through clips on YouTube. Some of the participants reported downloading Anglophone films. As mentioned above, the girls reported spending significantly more time using the Internet in Swedish than the boys did. The girls' diary comments clearly revealed that most of their Internet time meant socializing on Facebook.

As for the statistically significant gender-related difference regarding the time spent on playing digital games in English, both questionnaire and diary comments revealed that the boys and the girls generally favor different types of games, something that has been shown to be the case also among $9^{\text {th }}$ graders (Sundqvist, 2009, 2011; The Swedish Media Council, 2010) and $5^{\text {th }}$ graders (Sundqvist $\&$ Sylvén, 2012; Sylvén \& Sundqvist, 2012). It is common among the boys to play multiplayer action games such as Call of Duty, Counter-Strike, League of Legends, and Age of Empires Online. Also the MMORPG World of Warcraft is played by some of the boys in our study, despite their low age. A very popular game among the boys is Minecraft, a sandbox construction game that offers both singleplayer and multiplayer modes, and they also play sports games, such as FIFA and NHL. Among the girls who reported playing digital games, GoSupermodel is very popular, as is The Sims. Both are singleplayer simulation games, the former focusing on fashion and modeling and the latter on design and the lives of a fictive family (i.e., the Sims).

A Swedish Internet site that drew attention from both the boys and the girls is kpwebben.se, originally a quality magazine (Kamratposten) targeting children and young teens, but these days it has developed into a resourceful website offering news, tips for school, educational games, film and book reviews, chat forums and more.

\subsection{Three digital game groups}

As explained above, in order to answer research question 5 we divided our sample into three digital game groups. ${ }^{3}$ First of all, we find it relevant to cluster those who did not report any time at all for playing digital games in English into one group; i.e., non-gamers constitute digital game group 1 . The remaining participants all reported playing digital games, but to a varying degree; the highest reported value was 13.4 hours per week. Considering the size of our sample, it is suitable to distinguish between moderate and frequent gamers among the remaining participants. The problem is, of course, where to draw the line. In our study among $5^{\text {th }}$ graders (Sylvén \& Sundqvist, 2012), we drew the line at five hours per week. Considering the fact that the present learners are one year younger and overall spent slightly less time on digital gaming in English $(\mathrm{M}=1.4$ hours/week; $\mathrm{SD}=2.4)$ as compared to the $5^{\text {th }}$ graders $(\mathrm{M}=2.6$ hours/week; $\mathrm{SD}=4.3)$, we found it reasonable to lower the division between moderate and frequent gamers to four hours per week. Thus, the moderate gamers are those who reported playing some but less than four hours per week (digital game group 2). Finally, the frequent gamers (digital game group 3) reported playing digital games four hours or more per week. Just as the non-gamers, the

3 Of the 76 learners, $66(87 \%)$ completed the diary. 
Table 2 Three digital game groups

\begin{tabular}{|c|c|c|c|c|c|}
\hline \multirow[b]{2}{*}{ Digital game group } & \multirow[b]{2}{*}{$\mathrm{N}$} & \multicolumn{2}{|c|}{ Time interval (hours/week) } & \multirow[b]{2}{*}{ Mean (hours/week) } & \multirow[b]{2}{*}{ SD } \\
\hline & & From & To & & \\
\hline 1 (non-gamers) & 31 & 0 & 0 & 0 & 0 \\
\hline 2 (moderate gamers) & 27 & $>0$ & $<4$ & 1.5 & 1.1 \\
\hline 3 (frequent gamers) & 8 & $\geq 4$ & $\leq 14$ & 6.6 & 3.2 \\
\hline Total & 66 & $\geq 0$ & $\leq 14$ & 1.4 & 2.4 \\
\hline
\end{tabular}

Table 3 Gender distribution in the digital game groups

\begin{tabular}{|c|c|c|c|c|c|c|}
\hline \multirow[b]{2}{*}{ Digital game group } & \multicolumn{2}{|c|}{ Total } & \multicolumn{2}{|c|}{ Boys } & \multicolumn{2}{|c|}{ Girls } \\
\hline & $\mathrm{N}$ & $\%$ & $\mathrm{~N}$ & $\%$ & $\mathrm{~N}$ & $\%$ \\
\hline 1 (non-gamers) & 31 & 47 & 4 & 13 & 27 & 87 \\
\hline 2 (moderate gamers) & 27 & 41 & 11 & 41 & 16 & 59 \\
\hline 3 (frequent gamers) & 8 & 12 & 7 & 88 & 1 & 12 \\
\hline Total & 66 & 100 & 22 & 33 & 44 & 67 \\
\hline
\end{tabular}

moderate gamers constitute a rather large group $(\mathrm{N}=27)$. In contrast, the frequent gamers in digital game group 3 clearly make up the smallest group with eight members (see Table 2).

A one-way analysis of variance (ANOVA) indicated that there was a significant difference in the amount of time spent on gameplay among the learners in each of the three groups, $F(2,63)=83.65, p<.001$. S-N-K post hoc tests showed that digital game group 3 spent significantly more time on gaming than group $2(p<.05)$, and group 2 significantly more than group $1(p<.05)$.

5.3.1 Gender. The gender distribution in the groups is shown in Table 3. The nongamers group is predominantly female, with 27 girls and four boys. The distribution between boys and girls is fairly even in the moderate gamers group (16 girls, 11 boys). The frequent gamers group is in stark contrast to the non-gamers group, i.e., predominantly male with seven boys and one girl.

5.3.2 L1. In Swedish compulsory school, the majority of the pupils $(80 \%)$ have Swedish as their mother tongue and one out of five $(20 \%)$ has an L1 other than Swedish. ${ }^{4}$ Of the 66 learners constituting the digital game groups, most are L1 Swedish speakers (88\%), but eight (12\%) speak another L1; three speak L1 Russian, Spanish or Turkish, and the remaining five are bilinguals (Norwegian-Swedish, EnglishSwedish, Bosnian-Swedish, Persian-Swedish, Tagalog-Norwegian). When we examined

4 See http://www.skolverket.se 
the L1 distribution across the digital game groups, the ratio of students who had an L1 other than Swedish was 10\% (3 individuals) in the non-gamers group, 7\% (2) in the moderate gamers group, and 38\% (3) in the frequent gamers group. Thus, with regard to L1, learners with an L1 other than Swedish are overrepresented in the frequent gamers group.

5.3.3 Motivation for learning English. Motivation is important for all learning, not least language learning (Dörnyei \& Ushioda, 2011). In one questionnaire item, the informants were asked to rate the extent to which they agreed with the statement "English is interesting". Agreement is viewed as an indicator of motivation to learn English (cf. Guilloteaux \& Dörnyei, 2008; Sundqvist, 2009). The results revealed that all $(100 \%)$ of the learners in the frequent gamers group either 'agreed' or 'agreed strongly'. Although a large proportion of the learners in the non-gamers $(80.6 \%)$ and moderate gamers $(92.6 \%)$ groups also thought that English was interesting, the proportions were nevertheless smaller than among the frequent gamers. An examination of the ratio of learners who 'disagreed' or 'disagreed strongly' with the statement revealed that the largest proportion was found among the non-gamers (19.3\%, i.e., six individuals), indicating that they were the least motivated learners in our study together with another two $(7.4 \%)$ in the moderate gamers group.

5.3.4 Self-assessed English ability. In the questionnaire, the pupils self-assessed their English ability by answering the question "How good are you at English?". Four response options were given: 'very good, 'good', 'OK', and 'not very good'. Results showed that the $4^{\text {th }}$ graders overall rate their L2 English proficiency as high. At least half of the learners in each digital game group consider themselves to be 'good' or 'very good' at English (see Fig. 1). The non-gamers include the largest proportion of positive assessments, 'very good' and 'good' making up $67.8 \%$ of the group members (i.e., 21 individuals), but on the other hand there are also learners here who responded that they are 'not very good' at English (6.5\%; two individuals). Also among the moderate gamers, some consider themselves as 'not very good' $(11.1 \% ; 3$ individuals). In comparison, none of frequent gamers rated themselves that low.

5.3.5 Self-reported strategies related to speaking English. With previous research among adolescents about the relation between digital gaming and lowered anxiety for speaking English (Sundqvist, 2009) as a backdrop, a particular questionnaire item becomes relevant to investigate since it highlights learner strategies in a communicatively challenging situation: "When you are not able to come up with something to say, what do you do?". Five pre-determined strategy response options were given, followed by an open one, and the participants were instructed to tick all strategies they use. The results are shown in Table 4 as percentages of the number of in-group members ticking each specific strategy.

As for the open option, the participants mentioned these strategies (translated from Swedish): "I just try to get it out", "I start laughing", "I mumble", "I start giggling and ask a friend for help", "I just skip it", "I try to guess", "I ask my mother or father", and "I go 'uh... I dunno' and then I start giggling a little bit". 


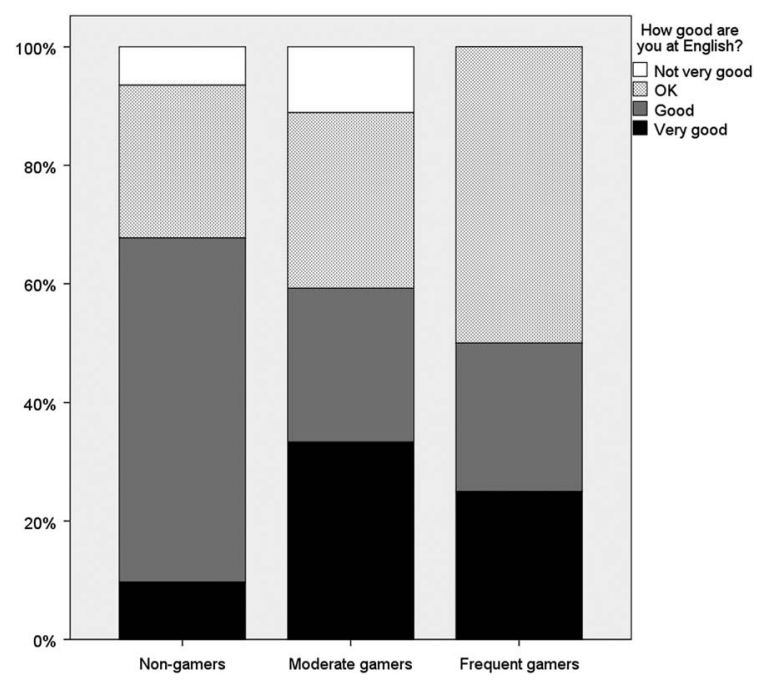

Fig. 1. Self-assessed English ability for the three digital game groups.

Table 4 Strategies used when not knowing what to say in English (\% of in-group members)

\begin{tabular}{|c|c|c|c|c|c|c|}
\hline $\begin{array}{l}\text { Digital } \\
\text { game } \\
\text { group }\end{array}$ & $\begin{array}{l}\text { I do } \\
\text { nothing }\end{array}$ & $\begin{array}{l}\text { I use } \\
\text { body } \\
\text { language }\end{array}$ & $\begin{array}{l}\text { I use another } \\
\text { word or } \\
\text { expression } \\
\text { in English }\end{array}$ & $\begin{array}{l}\text { I ask my } \\
\text { interlocutor } \\
\text { for help }\end{array}$ & $\begin{array}{l}\text { I use } \\
\text { Swedish or } \\
\text { another } \\
\text { language }\end{array}$ & $\begin{array}{l}\text { I do } \\
\text { something } \\
\text { else. } \\
\text { Example: ... }\end{array}$ \\
\hline 1 & 6.5 & 22.6 & 29.0 & 48.4 & 32.3 & 19.4 \\
\hline 2 & 11.1 & 29.6 & 29.6 & 48.1 & 40.7 & 11.1 \\
\hline 3 & 12.5 & 25.0 & 37.5 & 37.5 & 25.0 & 0.0 \\
\hline Total & 9.3 & 24.0 & 30.7 & 46.7 & 33.3 & 12.0 \\
\hline
\end{tabular}

Another question that tapped into the learners' self-assessed English ability was "Are you afraid of making mistakes when speaking in English?". The responses from the three groups (see Fig. 2) indicate that the level of speaking anxiety overall is low.

\section{Discussion}

We would like to begin by stressing the importance of not overgeneralizing our findings, particularly considering the external attrition and our fairly small sample. However, despite these shortcomings, it is worth pointing out that the sample is definitely varied enough to mirror learners from a typical Swedish town, and also that it is drawn from four different schools, which adds to the heterogeneity of the sample. Based on the collected data, we suggest that our study is relevant and ecologically valid, in particular since it brings forward insights into the language-related use of computers among YELLs outside of school, an underdeveloped area of research. In the following, we discuss our findings in the order of our research questions. 


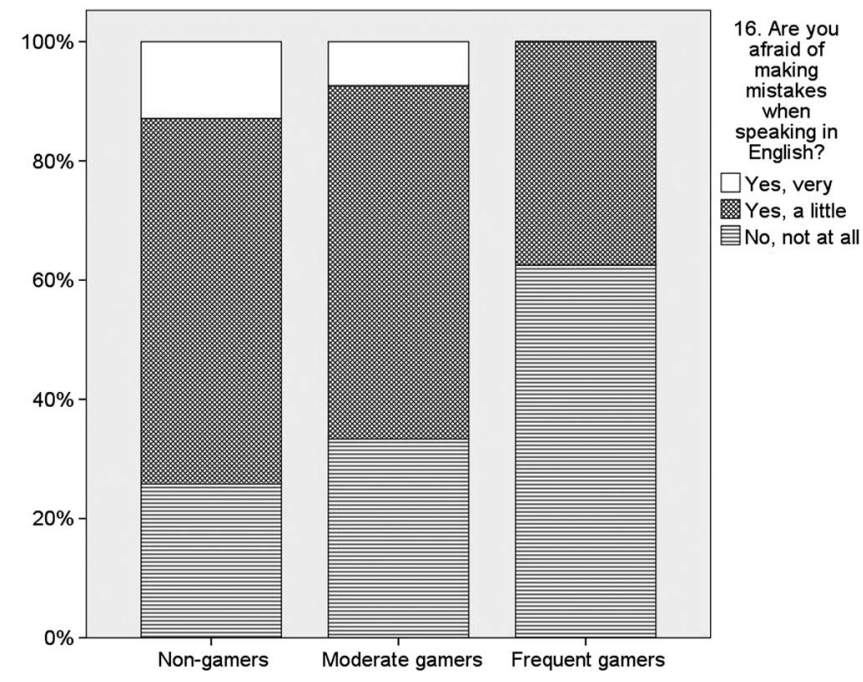

Fig. 2. Speaking anxiety for the three digital game groups.

In our study of $4^{\text {th }}$ graders, previous findings about pastime language-related activities in English among slightly older learners are corroborated (cf. Forsman, 2004; Olsson, 2011; Sundqvist, 2009, 2011; Sylvén, 2010). Just like secondary and upper secondary school pupils, the YELLs also enjoy watching English-speaking TV shows and films. As expected, they also enjoy listening to music (English lyrics) and playing digital games where collaboration in English is necessary. During a regular school week, which was measured here, the YELLs devote, on average, more than seven hours to English in out-of-school contexts. In comparison with the time allotted for English lessons in school, the schoolchildren in our study more than double that time when they get home. This has pedagogical implications and, most likely, also affects L2 English proficiency, which we return to in our concluding remarks.

Although both boys and girls devote a great deal of time to EE, at least the boys included in the present sample do so significantly more than the girls (11.5 vs. 5.1 hours/week). The reason for the time difference can be found in the boys' digital gaming habits, which amount to a fourth of their total EE time, and the fact that they watch more films than the girls. Conversely, as for language-related activities in Swedish, overall the girls "do more" and when the separate activities were investigated, the girls were found to devote significantly more time to using the Internet than the boys. More specifically, the girls socialize extensively on Facebook, whose main purpose is communication and social interaction. It is worth mentioning that the girls in our sample are at least two years younger than the (easily ignored/ overcome) age limit of 13 stipulated by Facebook. The most striking outcome of a comparison of the boys' and the girls' language-related computer use is that boys as a group seem driven by the competitive and interactive features offered in Englishmediated multiplayer and massively multiplayer games, whereas girls as a group seem driven by the socially oriented setup of a specific network community. This finding is in line with gender-related preferences in language learning described in 
Carr and Pauwels (2006), strengthening the stereotypical views of boys as more competitively inclined than girls and girls as more socially oriented than boys.

In order to examine the specific relation between digital gaming habits in English and (i) background variables (gender, L1) as well as (ii) language-related variables (self-reports about motivation, English ability, and strategies for speaking), the sample was clustered into the three digital game groups. The gender distribution in these groups is in line with that of our study among $5^{\text {th }}$ graders (Sylvén \& Sundqvist, 2012) and others (Kuppens, 2010; The Swedish Media Council, 2010). As for L1 background, learners with an L1 other than Swedish were clearly overrepresented among the frequent gamers, a finding that merits further reflection. We need to bear in mind that this is based on a small sample in a single study and may, thus, be a merely coincidental finding. Although speculative, it is possible that L2 Swedish YELLs find it particularly rewarding to take part in digital games that are mediated in English, a language other than their L2 and one that functions as a lingua franca in the participatory culture of digital games, thereby preventing these specific individuals from standing out as non-L1 speakers, a situation they are used to being in, daily in school.

With regard to the first of the three language-related background variables, motivation for learning English, the overall result is extremely positive: across all three groups, $80 \%$ or more 'agree' or 'strongly agree' with the statement "English is interesting". Notably, none of the frequent gamers disagreed; the only learners who did were in the other groups. Equally positive is the general picture regarding the $4^{\text {th }}$ graders' self-assessed English ability. Apparently, almost all the YELLs consider their general knowledge of English to be 'OK', 'good', or 'very good'. That is, regardless of which group learners belong to, they self-assess their L2 English proficiency as fairly high, a finding mirrored also in the responses regarding the level of speaking anxiety, which was generally low. However, when the three groups were compared regarding self-assessed English ability, contrary to our expectations, the frequent gamers group included proportionally fewer learners who rated themselves as 'good' or 'very good' than was the case in the other two groups. Considering previous findings, where frequent gamers have outperformed those who play less or not at all on a variety of aspects of English - writing proficiency (Olsson, 2011), oral proficiency and vocabulary (Sundqvist, 2009, 2011), vocabulary and listening as well as reading comprehension (Sylvén \& Sundqvist, 2012) - a possible explanation of this seemingly paradoxical outcome could be that the frequent gamers actually use English to such a great extent outside of school that, in so doing, they more easily realize their own shortcomings in terms of L2 English proficiency in a way that the moderate and non-gamers rarely get a chance to do. In addition, we notice that the frequent gamers group clearly was the most confident one in terms of speaking in English (see Fig. 2). Finally, linked to speaking are our findings about strategies used when not knowing what to say. While "giggling" seems to be a conscious strategy at least among some learners, most rely on paraphrasing or asking for help; both these latter strategies can be viewed as indicators of rather advanced language proficiency considering the age of the participants. The frequent gamers prioritize both these strategies, whereas paraphrasing is less frequently used by the other two groups. Code-switching to one's L1 was more common among the moderate gamers $(40.7 \%)$ 
and non-gamers $(32.3 \%)$ than among the frequent gamers $(25.0 \%)$. Altogether this could possibly reflect a generally higher level of language proficiency among the frequent gamers, or a gender effect as regards self-assessment of language ability, bearing in mind that all frequent gamers but one were boys. However, this is an area in need of further investigation.

\section{Concluding remarks and further research}

In many ways the present study among YELLs confirms previous studies among slightly older learners. What needs to be stressed is that already at this young age (10-11), children are exposed to and engage in EE activities extensively. In fact, the $4^{\text {th }}$ graders examined here devote more hours to English outside of school than there are hours in school devoted to English. This dissonance has pedagogical implications, making it necessary for L2 English teachers to bridge between learners' authentic EE experiences and the classroom (how this can be done, see Thorne \& Reinhardt, 2008). Our results also reveal that, when sitting at the computer, the boys use English to a greater extent than the girls, who tend to rely more on their L1. For future CALL research, a focus on language-related computer use from the perspective of gender is highly relevant, as are longitudinal studies on the topic, with the inclusion of achieved learning outcomes.

\section{References}

Airey, J. (2009) Science, language and literacy: Case studies of learning in Swedish university physics. $\mathrm{PhD}$, Uppsala University, Uppsala.

Boers, F., Eyckmans, J., Kappel, J., Stengers, H. and Demecheleer, M. (2006) Formulaic sequences and perceived oral proficiency: putting a lexical approach to the test. Language Teaching Research, 10(3): 245-261.

Carr, J. and Pauwels, A. (2006) Boys and foreign language learning: Real boys don't do languages. Basingstoke: Palgrave Macmillan.

Cheung, A. and Harrison, C. (1992) Microcomputer adventure games and second language acquisition: A study of Hong Kong tertiary students. In: Pennington, M. C. and Stevens, V. (eds.), Computers in applied linguistics. Clevedon: Multilingual Matters, 155-178.

Chik, A. (2012) Digital gameplay for autonomous foreign language learning: Gamers' and language teachers' perspectives. In: Reinders, H. (ed.), Digital games in language learning and teaching. Basingstoke: Palgrave Macmillan, 95-114.

Cobb, T. and Horst, M. (2011) Does Word Coach coach words? CALICO Journal, 28(3): 639-661.

deHaan, J., Reed, W. M. and Kuwada, K. (2010) The effects of interactivity with a music video game on second language vocabulary recall. Language Learning and Technology, 14(2): 74-94.

Dörnyei, Z. and Ushioda, E. (2011) Teaching and researching motivation (2 ed.). Harlow: Longman.

Enever, J. (ed.) (2011) ELLiE: Early language learning in Europe. Manchester: British Council.

Findahl, O. (2011) Svenskarna och Internet 2011. Stockholm: World Internet Institute, Medierådet och .se.

Forsman, L. (2004). Language, culture and context: Exploring knowledge and attitudes among Finland-Swedish EFL-students with particular focus on extracurricular influence. Licentiate's thesis, Åbo Akademi, Vasa. 
Gee, J. P. (2007) What video games have to teach us about learning and literacy. Revised and updated edition. New York, NY: Palgrave Macmillan.

Greenberg, B. S., Sherry, J., Lachlan, K., Lucas, K. and Holmstrom, A. (2010) Orientations to video games among gender and age groups. Simulation \& Gaming, 41(2): 238-259.

Guilloteaux, M.-J. and Dörnyei, Z. (2008) Motivating language learners: A classroomoriented investigation of the effects of motivational strategies on student motivation. TESOL Quarterly, 42(1): 55-77.

Hyltenstam, K. (2002) Engelskundervisning i Sverige. Mål i mun - Förslag till handlingsprogram för svenska språket. SOU 2002:27. Bilagor. Stockholm: Regeringskansliet, 45-72.

Kachru, B. B. (1985) Standards, codification and sociolinguistic realism: The English in the outer circle. In: Quirk, R. and Widdowson, H. G. (eds.), English in the world: Teaching and learning the language and literatures. Cambridge: Cambridge University Press for the British Council, 11-30.

Kuppens, A. H. (2010) Incidental foreign language acquisition from media exposure. Learning, Media and Technology, 35(1): 65-85.

Lindgren, E. and Muñoz, C. (2012) The influence of exposure, parents, and linguistic distance on young European learners' foreign language comprehension. International Journal of Multilingualism, doi: 10.1080/14790718.2012.679275 (ePub before print).

Miller, M. and Hegelheimer, V. (2006) The SIMs meet ESL. Incorporating authentic computer simulation games into the language classroom. Interactive Technology \& Smart Edcuation, 3(4): 311-328.

Mitra, S., Dangwal, R., Chatterjee, S., Jha, S., Bisht, R. S. and Kapur, P. (2005) Acquisition of computing literacy on shared public computers: Children and the "hole in the wall". Australasian Journal of Educational Technology, 21(3): 407-426. http://www.ascilite.org.au/ajet/ajet21/ mitra.html.

Nikolov, M. (ed.) (2009) Early learning of modern foreign languages: Processes and outcomes. Bristol: Multilingual Matters.

Odera, F. Y. (2011) Learning English language by radio in primary schools in Kenya. US-China Education Review A, 7: 960-966.

Olsson, E. (2011). "Everything I read on the Internet is in English" - On the impact of extramural English on Swedish 16-year-old pupils' writing proficiency. Licentiate's thesis, University of Gothenburg, Gothenburg.

Persson, L. (2011). Language learning in the 21st century: Foreign language acquisition through informal language contact at home. Paper presented at the 21st Annual Conference of the European Second Language Association, EUROSLA 21, Stockholm University, Stockholm, Sweden.

Peterson, M. (2012) Learner interaction in a massively multiplayer online role playing game (MMORPG): A sociocultural discourse analysis. ReCALL, 24(3): 361-380.

Piirainen-Marsh, A. and Tainio, L. (2009) Other-repetition as a resource for participation in the activity of playing a video game. The Modern Language Journal, 93(2): 153-169.

Purushotma, R. (2005) You're not studying, you're just... Language Learning \& Technology, 9(1): 80-96.

Ramírez Verdugo, D. and Alonso Belmonte, I. (2007) Using digital stories to improve listening comprehension with Spanish young learners of English. Language Learning \& Technology, 11(1): 87-101.

Ranalli, J. (2008) Learning English with The Sims: exploiting authentic computer simulation games for L2 learning. Computer Assisted Language Learning, 21(5): 441-455.

Rankin, Y. A., Gold, R., and Gooch, B. (2006). 3D role-playing games as language learning tools. Paper presented at the EuroGraphics 2006, September 4-8, 2006, Vienna, Austria. http://www.thegooch.org/Publications/PDFs/Rankin_Gold_Gooch.pdf 
Rankin, Y. A., McNeal, M., Shute, M. W. and Gooch, B. (2008) User centered game design: Evaluating massively multiplayer online role playing games for second language acquisition. Paper presented at the Sandbox '08. Proceedings of the 2008 ACM SIGGRAPH symposium on Video games. Los Angeles, CA, 43-49. http://doi.acm.org/10.1145/1401843.1401851

Reichl, R. V. (2012) Sprites and rules: What ERPs and procedural memory can tell us about video games and language learning. In: Reinders, H. (ed.), Digital games in language learning and teaching. Basingstoke: Palgrave Macmillan, 139-155.

Reinders, H. (ed.) (2012) Digital games in language learning and teaching. Basingstoke: Palgrave Macmillan.

Reinders, H. and Wattana, S. (2011) Learn English or die: The effects of digital games on interaction and willingness to communicate in a foreign language. Digital Culture and Education, 3(1): 4-28.

Sundqvist, P. (2009) Extramural English matters: Out-of-school English and its impact on Swedish ninth graders' oral proficiency and vocabulary. $\mathrm{PhD}$, Karlstad University, Karlstad.

Sundqvist, P. (2011) A possible path to progress: Out-of-school English language learners in Sweden. In: Benson, P. and Reinders, H. (eds.), Beyond the language classroom. Basingstoke: Palgrave Macmillan, 106-118.

Sundqvist, P. and Sylvén, L. K. (2012) World of VocCraft: Computer games and Swedish learners' L2 vocabulary. In: Reinders, H. (ed.), Digital games in language learning and teaching. Basingstoke: Palgrave Macmillan, 189-208.

Sylvén, L. K. (2007) Are The Simpsons welcome in the CLIL classroom? VIEWS - Vienna English Working Papers, 16(3): 53-59.

Sylvén, L. K. (2010) Teaching in English or English teaching? On the effects of content and language integrated learning on Swedish learners' incidental vocabulary acquisition. Gothenburg: Acta Universitatis Gothoburgensis.

Sylvén, L. K. and Sundqvist, P. (2012) Gaming as extramural English L2 learning and L2 proficiency among young learners. $\operatorname{Re} C A L L, \mathbf{2 4}(3)$ : 302-321.

Söderlundh, H. (2010) Internationella universitet - lokala språkval. Om bruket av talad svenska $i$ engelskspråkiga kursmiljöer. $\mathrm{PhD}$, Uppsala University, Uppsala.

The Swedish Media Council (2010) Ungar \& Medier 2010. Stockholm: Regeringskansliet.

The Swedish National Agency of Education (2004) Nationella utvärderingen av grundskolan 2003: huvudrapport - svenska/svenska som andra språk, engelska, matematik och undersökningen $i$ arskurs 5. Skolverkets rapport 251. Stockholm: The Swedish National Agency of Education.

The Swedish National Agency of Education (2011a) Curriculum for the compulsory school, preschool class and leisure-time centre 2011. Stockholm: The Swedish National Agency of Education.

The Swedish National Agency of Education (2011b) Upper secondary school 2011. Stockholm: The Swedish National Agency of Education.

Thorne, S. L. and Reinhardt, J. (2008) "Bridging activities," new media literacies, and advanced foreign language proficiency. CALICO Journal, 25(3): 558-572.

Turgut, Y. and Irgin, P. (2009) Young learners' language learning via computer games. Procedia Social and Behavioral Sciences, 1(1): 760-764.

Ushioda, E. (2013) Motivation and ELT: Global issues and local concerns. In: Ushioda, E. (ed.), International perspectives on motivation: Language learning and professional challenges. Basingstoke: Palgrave Macmillan, 1-17.

Viberg, Å. (2000) Tvåspråkighet och inlärning av språk i och utanför skolan. Språk 2000:18. Stockholm: Skolverket, 27-41.

Wu, S., Franken, M. and Witten, I. H. (2012) Collocation games from a language corpus. In: Reinders, H. (ed.), Digital games in language learning and teaching. Basingstoke: Palgrave Macmillan, 209-229. 


\section{Appendix 1}

\section{Language diary (sample page, extramural English, Monday, translated from Swedish)}

\section{Monday}

\section{ENGLISH}

What do you do in English in your spare time?

\begin{tabular}{|l|l|l|}
\hline Reading books & Title: & minutes, write 0 hrs. 25 min. \\
\hline Reading newspapers/magazines & Name: & \\
\hline $\begin{array}{l}\text { Watching TV-programs (on TV } \\
\text { or computer) }\end{array}$ & Name: & \\
\hline $\begin{array}{l}\text { Watching films (at the movie } \\
\text { theater, on TV, video, DVD, } \\
\text { computer, etc.) }\end{array}$ & Name: & \\
\hline $\begin{array}{l}\text { Using the Internet } \\
\text { Playing digital games (on a } \\
\text { computer, PlayStation, Xbox } \\
\text { etc.) }\end{array}$ & Name: & \\
\hline $\begin{array}{l}\text { Listening to music } \\
\text { Other activity }\end{array}$ & Name: & \\
\hline
\end{tabular}

